\title{
Synergistic Effects of 5-Fluorouracil and Gambogenic Acid on A549 Cells: Activation of Cell Death Caused by Apoptotic and Necroptotic Mechanisms via the ROS-Mitochondria Pathway
}

\author{
Jingjing Su, ${ }^{a, \#}$ Hui Cheng, ${ }^{a, \#}$ Dandan Zhang, ${ }^{a}$ Mei Wang, ${ }^{a}$ Chenye Xie, ${ }^{a}$ Yawen Hu, ${ }^{a}$ \\ Hebron Chun-Wei Chang, ${ }^{*}, b$ and Qinglin $\mathrm{Li}^{*}, a, \uparrow$ \\ ${ }^{a}$ Key Laboratory of Xin'an Medicine, Ministry of Education, Anhui Province Key Laboratory of R\&D of Chinese \\ Medicine, Anhui University of Chinese Medicine, Anhui Academy of Chinese Medicine; Hefei 230038, China: and \\ ${ }^{b}$ Department of Biotechnology, Asia University; Taichung 41354, Taiwan. \\ Received December 16, 2013; accepted May 21, 2014
}

5-Fluorouracil (5-FU) is one of the widely used chemotherapeutic drugs for various cancer treatments, but its chemo-drug resistance is a major obstacle in clinical settings. The anticancer effects of gambogenic acid (GNA) and its potential mechanisms have been well documented in the past few years. In this study, we determined the synergistic inhibitory effects of GNA and 5-FU on A549 human lung cancer cells. 5-FU combined with GNA inhibited the viability of A549 cells in a concentration-dependent manner. The mitochondrial tolerance of this two-kind of drugs combination treatment was stronger than a single-drug treatment. Combination treatment caused a morphological change of A549 cells. Flow cytometric evidence indicated that the combined treatment caused significant cell death, with the death rate of A549 cells treated with combination drugs showing a time-dependent manner. Furthermore, combination treatment of GNA and 5-FU showed up-regulated of caspase-3, caspase-9, bax, RIP1, apoptosis-inducing factor (AIF), voltage-dependent anion channel (VDAC), cytochrome $c$ and cyclophilin D and down-regulated bcl-2. In conclusion, in addition to the activation of caspase-dependent apoptosis, the combination of GNA and 5-FU might also cause cell death of A549 cells by activating caspase-independent necroptosis. These mechanisms may be due to the toxicity of targeted toxin to mitochondria via the mitochondrial pathway.

Key words 5-fluorouracil; gambogenic acid; synergism; A549; necroptosis

Responses of single-agent treatment for cancer chemotherapy are relatively short and toxic to normal tissues. However, single-agent treatment has been one of the major obstacles to successful cancer chemotherapy. Combination or multi-component therapy, in which two or more kinds of drugs are used at the same time, is a proven treatment for cancer diseases as previously reported by Fitzgerald et al. ${ }^{1)}$ Therefore, combined treatments with several chemotherapy drugs are often used not only to enhance the effects, but also to reduce the toxicity of these drugs. ${ }^{1-5)}$

Most anticancer agent mediated death of cancer cells through the induction of apoptosis. 5-Fluorouracil (5-FU), belongs to anti-metabolic chemotherapeutics, is a fluorinated pyrimidine which is widely used in the treatment of a variety of solid tumors. ${ }^{5,6)}$ When 5-FU is used alone, it produces an objective response to $14-18 \%$ of non-small lung cell carcinoma (NSCLC) patients. Using the combination of 5-FU and other chemotherapeutic agents, the response rate was $33-58 \%$. $^{7}$ A549 cells are adenocarcinomic human alveolar basal epithelial cells, which are widely used as a model for type II pulmonary epithelial cell model for drug metabolism. Gamboge is the dry resin of Garcinia hanburyi Hook. f. (Guttiferae) and was found with various bioactivities including detoxification, homeostasis, anti-inflammatory and parasiticidal effects. Gambogenic acid (GNA) is one of the main components of Gamboge. ${ }^{8)}$ Previous studies suggested that GNA might be a potential

\footnotetext{
The authors declare no conflict of interest.

${ }^{\#}$ These authors contributed equally to this work.

${ }^{\dagger}$ Present address: No. 103, Experimental Center for Scientific Research, Anhui University of Chinese Medicine; Meishan Road, Anhui Province 230038, China.
}

anticancer drug candidate..$^{9-11)}$ It was also reported that GNA activated apoptosis in many cancer cell lines in vitro, ${ }^{9,12,13)}$ with tumor growing inhibitory activity for A549 in vivo.

In this study, we discussed the inhibitory effects of the combination of GNA and 5-FU on A549 cells. All the results showed that the combination of GNA and 5-FU induced cell death by activating the mitochondrial pathway. In the present study, we demonstrate the synergistic effects of 5-FU combined with GNA for A549 cells.

\section{MATERIALS AND METHODS}

Materials 5-FU was purchased from Sigma Company (Sigma, St. Louis, MO, U.S.A.) and was dissolved in dimethyl sulfoxide (DMSO) (Sigma-Aldrich, St. Louis, MO, U.S.A.) (the final concentration of DMSO was $0.1 \%$ ). The solution was diluted to various concentrations with complete culture medium for further studies.

GNA $(>99.0 \%)$ was purified using HPLC by Dr. X. Wang in Anhui University of Chinese Medicine. Purified GNA was dissolved in Nutrient Mixture F-12 Ham's Kaighn's Modification (F12K, GIBCO, NY, U.S.A.) and kept at $-20^{\circ} \mathrm{C}$. GNA was diluted as obligatory factors in complete culture medium before immediately used.

Hochest 33258 staining assay kit and JC-1 assay kit were purchased from Molecular Probes (Beyotime Institute of Biotechnology, Shanghai, China). 2,'7'-Dichlorodihydrofluorescein diacetate (DCFH-DA) was purchased from Genmed Scientifics, Inc., U.S.A. (Shanghai, China). Rhodamine-123 (Rho-123) was purchased from Molecular Probes (Eugene, OR, U.S.A.). Annexin V-fluorescein isothiocyanate (FITC)/ propidium iodide (PI) apoptosis detection kit was from AV/ 
PI (Keygen Biotechnology, Nanjing, China). Caspase-3 activity assay kit was from Bestbio (Beijing, China). Primary antibodies for caspase-3, caspase-9, bcl-2, voltage-dependent anion channel (VDAC), apoptosis-inducing factor (AIF) antibodies were obtained from Cell Signaling Technology (Beverly, MA, U.S.A.). Bax and $\beta$-actin antibodies were from Bioworld (Bioworld Technology, MN, U.S.A.). RIP1 antibody was from BD Biosciences (CA, U.S.A.). Cyclophilin D antibody was from Santa Cruz (CA, U.S.A.). Cytochrome $c$ was from Epitomics (Burlingame, U.S.A.). Chemiluminescent enhanced chemiluminescence (ECL) reagent was from Millipore Co. (Billerica, MA, U.S.A.). Blue Basic Autorad Film was from ISC Bioexpress (Kaysville, UT, U.S.A.). The pan-caspase inhibitor, z-VAD-fmk, and necroptosis inhibitor, Necrostatin-1 (Nec-1), were from Promega Biotec (Madison, WI, U.S.A.). Diphenyleneiodonium (DPI) was from Sigma-Aldrich. All other common chemicals were from Abcam (Cambridge, MA, U.S.A.) or Sigma-Aldrich.

Cell Culture Human lung adenocarcinoma cell line A549 was obtained from Cell Bank of Shanghai Institute of Biochemistry \& Cell Biology, China Academy of Sciences. The cells were cultured in F12K supplemented with 10\% heatinactivated fetal bovine serum (FBS), $0.25 \% \mathrm{NaHCO}_{3}, 100 \mathrm{U} /$ $\mathrm{mL}$ penicillin $\mathrm{G}$ and $100 \mathrm{U} / \mathrm{mL}$ streptomycin. The cells were cultivated in the humidified atmosphere with $5 \% \mathrm{CO}_{2}$ at $37^{\circ} \mathrm{C}$ for $24 \mathrm{~h}$ at the beginning of each experiment.

Cell Growth Inhibition Assay After exposure to GNA, 5 -FU or the combination of GNA and 5-FU for 24h, 3-(4,5dimethylthiazol-2-yl)-2,5-diphenyltetrazolium bromide (MTT) $(5.0 \mathrm{mg} / \mathrm{mL}$, Sigma) was added to culture medium and incubated for another $4 \mathrm{~h}$ at $37^{\circ} \mathrm{C}$. Cell inhibitory ratio was calculated by the following formula: fractions affected $(\mathrm{fa})=$ inhibitory rate $(\%)=(1-$ avarage absorbance of treated group/average absorbance of control group) $\times 100 \%$.

Effects Evaluation for Combined Drugs To detect the inhibitory effects of the combination of these two drugs, cells were exposed to both of GNA and 5-FU concurrently for $24 \mathrm{~h}$. The inhibitory effects were assessed by MTT assay, and the inhibition rates were analyzed according to the method of Chou and Talalay ${ }^{14}$ by using the CalcuSyn software program (Biosoft, Cambridge, United Kingdom). The result of combination index (CI) is a quantitative measure of the degree of interaction between drugs. $\mathrm{CI}<1$, synergism; $\mathrm{CI}=1$, denotes additive effects; CI $>1$, denotes antagonism. The CI value was calculated as follows:

$$
\begin{aligned}
& \mathrm{CI}= \mathrm{D} 1 / \mathrm{Dx} 1+\mathrm{D} 2 / \mathrm{Dx} 2 \\
& \mathrm{fa}= \text { fraction of system affected by drug, } \\
& \mathrm{fu}= \text { fraction of system unaffected by drug, } \\
& \text { since } \mathrm{fa}+\mathrm{fu}=1, \mathrm{fu}=1-\mathrm{fa}, \\
& \mathrm{D} 1, \mathrm{D} 2, \mathrm{D}(1,2)=\text { dose of } 5-\mathrm{FU}, \mathrm{GNA} \text { or mixture of } \\
& \\
& \quad \mathrm{GNA} \text { and } 5 \text {-FU (in specified ratio), respectively. } \\
& \mathrm{Dx} 1, \mathrm{Dx} 2, \mathrm{Dx}(1,2)=\text { dose of } 5-\mathrm{FU}, \mathrm{GNA} \text { and mixture of } \\
& \text { GNA and 5-FU (in specified ratio) required to } \\
& \text { produce a median effects, e.g. } \mathrm{IC}_{50}, \mathrm{ED}_{50} \text { or } \mathrm{LD}_{50} . \\
& x= \text { the slope of the median-effect plot, } \\
& \text { in which } y=\log (\mathrm{fa} / \mathrm{fu}) \text { and } x=\log (D) .
\end{aligned}
$$

The experiments were performed in triplicates. One of the plates was used to determine the dose-response relation of 5-FU alone at concentrations of $0.1,0.2,0.3,0.4,0.6,0.8$, $1.2 \mathrm{~mm}$. Another plate was used to determine the dose-response relation of GNA alone at concentrations of 0.313 , $0.625,1.25,2.5,5,7.5,10 \mu \mathrm{M}$. Drug interaction between GNA and 5-FU was assessed, with various concentrations of 0.1 , $0.2,0.3,0.4,0.6,0.8,1.2 \mathrm{~mm}$ of 5 -FU and $0.25,0.5,1,2,4$, $6,8 \mu \mathrm{m}$ of GNA, using a $\mathrm{CI}$, where $\mathrm{CI}<1, \mathrm{CI}=1$, and $\mathrm{CI}>1$ indicated synergistic, additive, and antagonistic effects respectively.

Cell Morphological Assessment The method used in this study was modified based on the previous reports. ${ }^{15,16)}$ A549 cells were seeded in the 6 -wells plates. After the cells growing to approximately $60 \%$ confluence, they were washed and treated with GNA or 5-FU alone or in combination for $24 \mathrm{~h}$. At the end of the incubation period, cells were fixed, washed twice with PBS and stained with Hoechst 33258 at $10 \mu \mathrm{M}$ for $3 \mathrm{~min}$ at room temperature. Cell morphology was observed under inverted fluorescence microscope (Leica, Germany). Fragmented or condensed nuclei were scored as apoptotic body.

Cultured cells were washed once in PBS and fixed for $30 \mathrm{~min}$ in $2.5 \%$ glutaraldehyde, then were washed with $0.1 \mathrm{~mol} / \mathrm{L}$ sodium phosphate buffer ( $\mathrm{pH} 7.4)$, dehydrated in alcohol, embedded in EPOR812, then ultrathin sliced, stained with uranium acetate and citromalic acid, and were observed under a transmission electron microscope (HITACHI-600, Japan) to detect and record the morphological changes of cells and mitochondria.

Flow Cytometry Analysis A549 cells were treated with GNA or 5-FU alone or treated with combinational drugs for $12 \mathrm{~h}$. After treatment, cells were fixed with $70 \%$ ethanol, incubated with RNase A $(20 \mu \mathrm{g} / \mathrm{mL})$ and PI $(50 \mu \mathrm{g} / \mathrm{mL})$, and then analyzed on a FACScan flow cytometer (CA, U.S.A.).

Apopotic cells were identified by the Annexin V-FITC and PI apoptosis detection kit according to the manufacturer's instructions. Briefly, cultured A549 cells were harvested and washed with phosphate buffered saline (PBS) and re-suspended with the binding buffer, followed by Annexin V-FITC incubation for $10 \mathrm{~min}$ and then performed PI stain for another $10 \mathrm{~min}$ at room temperature in dark. Flow cytometric analysis was performed after supravital stain immediately.

A549 cells were incubated for $24 \mathrm{~h}$ and mitochondrial membrane potential (MMP) was measured respectively with Rho-123, JC-1 by flow cytometry after treatment. The argon laser source was used to emit a wavelength of $488 \mathrm{~nm}$ for excitation, and at least 10000 events were analyzed.

Intracellular reactive oxygen species (ROS) generation was measured by using DCFH-DA. Cells were seeded in 6-well plates at a density of $1 \times 105$ cells per well and cultured for $24 \mathrm{~h}$. After treatment, $20 \mu \mathrm{M}$ DCFH-DA was added and cells were determined within $1 \mathrm{~h}$ by flow cytometry to analyze formation of the fluorescent compound 2,'7'-dichlorofluorescein (DCF) (FACScan, Becton Dickinson, U.S.A.). Analysis and data acquisition were performed in a Becton Dickinson FACSCalibur flow cytometer by using CXP Analysis software.

Cell Mortality The cell mortality was evaluated by Trypan blue assay (Beyotime Institute of Biotechnology, China). After $30 \mathrm{~min}$ diphenyleneiodoniumcloride (DPI) pretreatment with different concentration, A549 cells were incubated in the 6 -well plates $\left(1 \times 10^{5}\right.$ cells per well) for $24 \mathrm{~h}$. GNA, 5-FU and 
the combination of GNA and 5-FU were introduced separately to wells for another $24 \mathrm{~h}$. The supernatant was collected and the cells were detached with $200 \mu \mathrm{L}$ trypsin-ethylenediaminetetraacetic acid (EDTA) solution. The mixture of the supernatant and detached cells was centrifugated. Then, the residue was added with $800 \mu \mathrm{L}$ Trypan blue solution and dispersed. Cells were counted using cytometer after $5 \mathrm{~min}$ staining. The dead cells were stained with blue color. Cell inhibitory ratio was calculated by the following formula: Cell mortality $(\%)=($ the dead cell number/the total number $) \times 100 \%$.

Caspase Activity Assay Measurements for activities of caspase-3 and caspase-9 were achieved using a commercialized kit. After the A549 cells were incubated with GNA, 5 -FU or the combination of these two drugs for $24 \mathrm{~h}$, cells were collected by centrifugation at $10000 \times \boldsymbol{g}$ for $5 \mathrm{~min}$ at $4^{\circ} \mathrm{C}$, and the cell pellets were lysed in $100 \mu \mathrm{L}$ of the supplied lysis buffer (1\% NP-40, $20 \mathrm{~mm}$ Tris-HCl (PH 7.5), $137 \mathrm{~mm} \mathrm{Nad}$ and $10 \%$ glycerol) containing $10 \mu \mathrm{L}$ caspase-3 substrate $(2 \mathrm{~mm}$ AcDEVD-pNA) or $10 \mu \mathrm{L}$ caspase- 9 substrate ( $2 \mathrm{~mm}$ Ac-LEHDpNA). The supernatants were collected and incubated at $37^{\circ} \mathrm{C}$, with the supplied reaction buffer, which contained dithiothreitol and substrates. The caspase activity was then determined by measuring changes in the absorbance at $405 \mathrm{~nm}$ using a microplate reader.

Western Blot Analysis A549 cells were incubated for $24 \mathrm{~h}$ with GNA or 5-FU respectively, or in combination. Protein of A549 cells were collected and washed twice with icecold PBS before lysis. After the cells were treated for $30 \mathrm{~min}$ with lysis buffer (100 mM Tris- $\mathrm{Cl}$, pH 6.8, $1 \mathrm{~mm}$ phenylmethylsulfonyl fluoride (PMSF)), the lysates were ultra-centrifuged at $12000 \times \boldsymbol{g}$ for $30 \mathrm{~min}$. Supernatants were collected for protein assay. Aliquots of protein ( $25 \mu \mathrm{g} /$ lane) were resolved in $4-20 \%$ sodium dodecyl sulfate-polyacrylamide gel electrophoresis (SDS-PAGE), and then transferred onto nitrocellulose filter (NC) membranes. After blocking ( $5 \%$ nonfat dry milk) for $3 \mathrm{~h}$, $\mathrm{NC}$ membranes were then incubated with primary antibodies (1:1000) overnight at $4^{\circ} \mathrm{C}$. Membranes were subsequently incubated with appropriate horseradish peroxidase-conjugated secondary antibody for $2 \mathrm{~h}$. These results were detected using chemiluminescent ECL reagent, and developed on Blue Basic Autorad Film. All Western blotting analysis was repeated for $2-3$ times and re-probed with polyclonal anti- $\beta$-actin antibody to ascertain equal loading of protein.

Satistical Analysis All results were represented as mean \pm S.D. from triplicate independent experiments. Statistical analyses were performed by using an unpaired, two-tailed Student's $t$-test. All comparisons were made relative to untreated control and statistical significance was accepted at $* p<0.05$ and $* * p<0.01$.

\section{RESULTS}

Cell Viability and Combination Index of Two-Drug Mixture The inhibition of GNA or 5-FU on cell viability in A549 cells was assessed after a $24 \mathrm{~h}$-exposure, following a $24 \mathrm{~h}$-cultivating in drug-free medium. A concentration-dependent inhibitory effect on cell growth was observed. As shown in Figs. $1 \mathrm{~A}$ and $1 \mathrm{~B}$, the $\mathrm{IC}_{50}$ of GNA and 5-FU was $2.832 \mathrm{~mm}$ and $1073.3 \mu \mathrm{M}$ for A549 cells, respectively. The 5-FU or GNA alone or a combinational application inhibited the growth of A549 cells in a concentration-dependent mode. The combi-
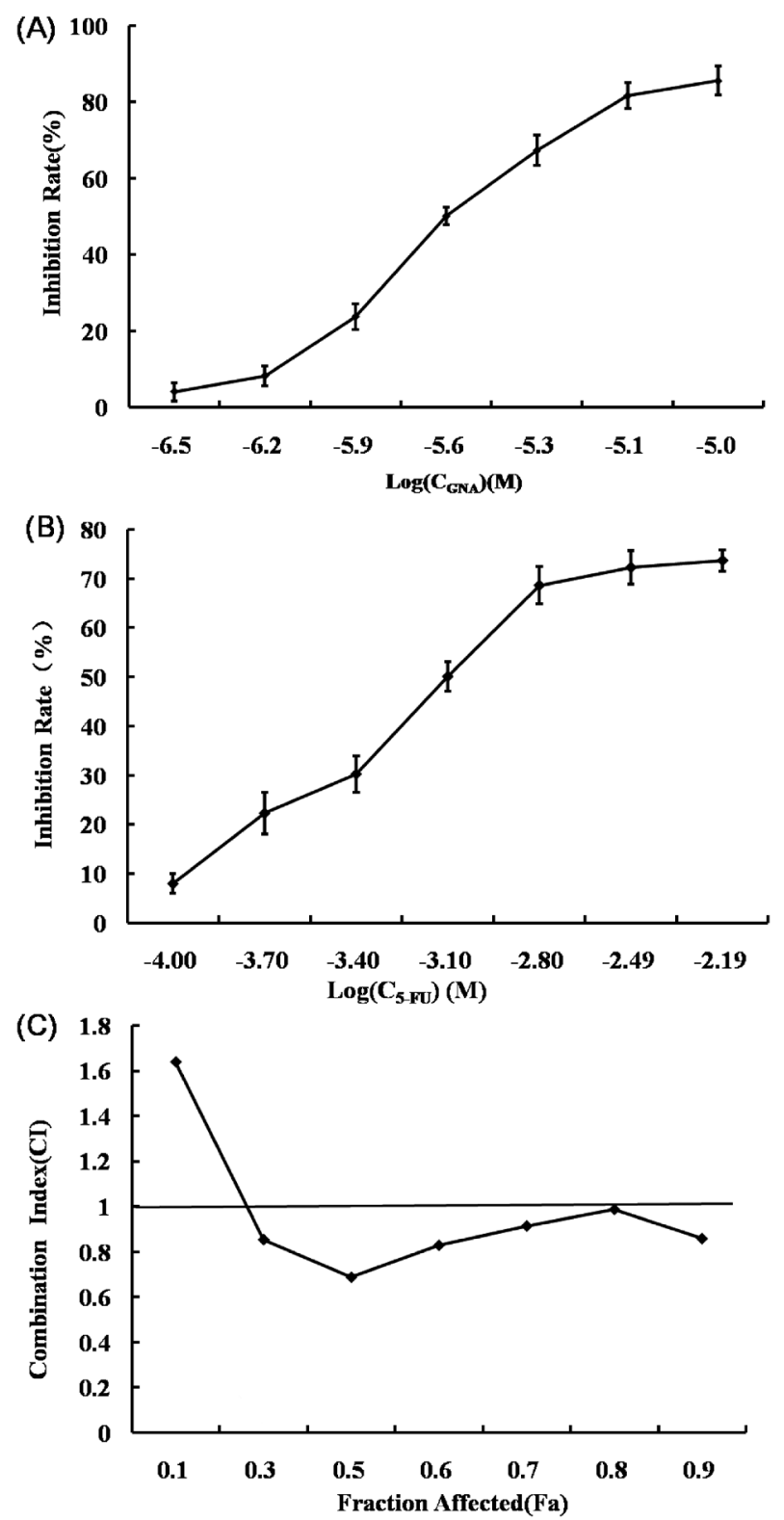

Fig. 1. Effects of Two Single Drugs on A549 Cells and the Combination Index of Two Drugs

A549 cells were treated with various concentration of GNA (A) or 5-FU (B) alone for $24 \mathrm{~h}$. Cell viability was determined using the MTT assay. After treated with combination of GNA $(1 \mu \mathrm{M})$ and 5-FU $(363.3 \mu \mathrm{M})$ for $24 \mathrm{~h}$, the CI $v s$. fraction affected (fa) (C) values were determined to use the previous described Materials and Methods. When the fractions effects are higher than $0.45, \mathrm{CI}<1$ indicates a synergistic effects.

nation index (CI) was less than 1 at $24 \mathrm{~h}$ when the fa was higher than 0.48, which indicated that GNA and 5-FU had a synergistic effect. When the combination index was more than 1 at $24 \mathrm{~h}$ while $\mathrm{fa}<0.32$, indicated that GNA and 5-FU had a antagonistic effect (Fig. 1C). The combinational application of GNA and 5-FU demonstrated significant synergistic therapeutic efficacy, especially in the combination of $363.3 \mu \mathrm{M} \mathrm{5-FU}$ and $1.0 \mu \mathrm{M}$ GNA, which produced a $50.0 \%$ suppression rate of cell growth, whereas, $363.3 \mu \mathrm{m} 5$-FU or $1.0 \mu \mathrm{m}$ GNA alone showed inhibition rates of $22.2 \%$ and $17.9 \%$, respectively. The dose combination of $363.3 \mu \mathrm{m} \mathrm{5-FU}$ and $1 \mu \mathrm{M}$ GNA was selected for all further iatrology studies.

Cell Death Induced by 5-FU, GNA or Combination of GNA and 5-FU Cell death induced by 5-FU, GNA or a 
(A)

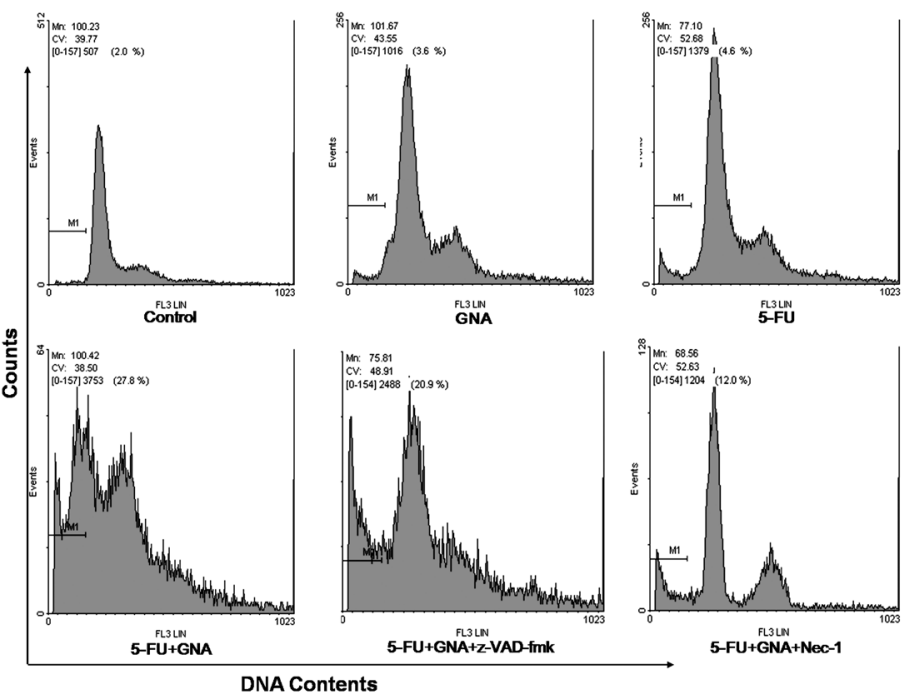

(ii)

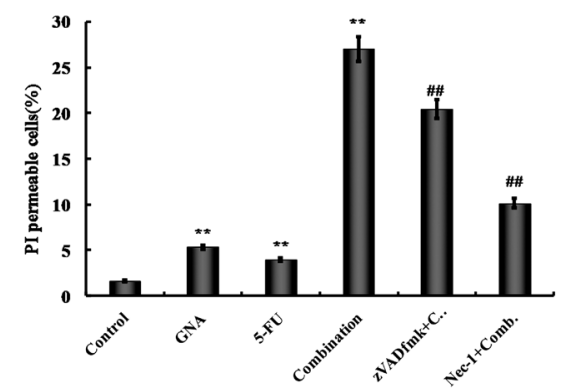

(B)

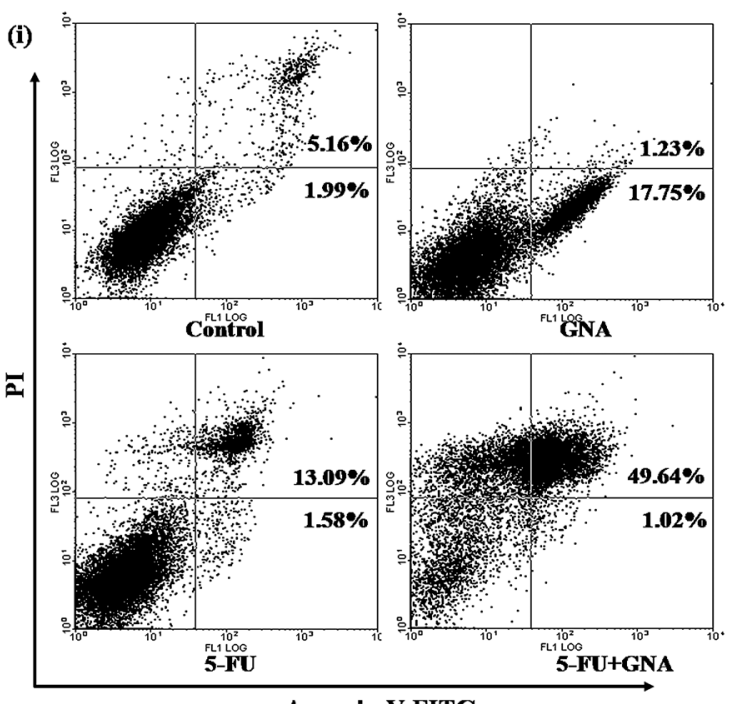

(ii)

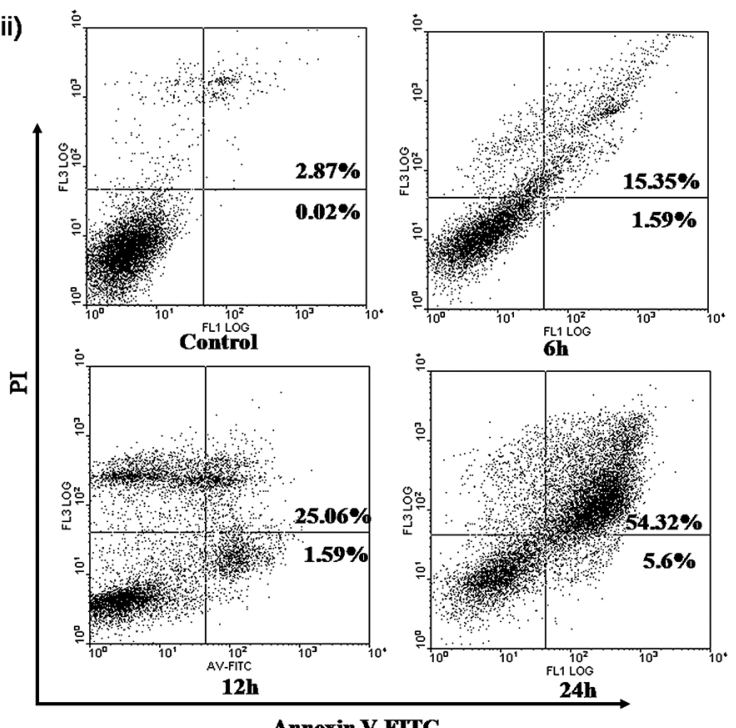

Annexin V-FITC

Fig. 2. Flow Cytometry Analysis of the Effects of GNA or 5-FU or Combination on Cell Death in A549 Cells, Comb., Combination (Ai)

Different drugs treated with A549 cells for $12 \mathrm{~h}$, at least in 3 independent experiments, ${ }^{* *} p<0.01$ compared with drug free group, ${ }^{\# \#} p<0.01$ compared with drugs combination treated group (Aii). Apoptosis and necroptosis in A549 cells flow cytometer method quantitatively. A549 cells were treated with two single drugs or in combination (B). A549 cells were treated with GNA $(1 \mu \mathrm{M})$ or 5-FU $(363.3 \mu \mathrm{M})$ either in combination or alone for $24 \mathrm{~h}$ (Bi), following by staining with Annexin V and PI, and flow cytometry analysis. Early apoptotic cells were defined as Annexin-V-positive, PI-negative cells, non-viable apoptotic cell and necroptotic cell were defined as Annexin-Vpositive, PI-positive cells. A549 cells were treated with combination for $0 \mathrm{~h}, 6 \mathrm{~h}, 12 \mathrm{~h}, 24 \mathrm{~h}$ (Bii).

combination was quantitatively analyzed by PI stained and AV/PI double stained assay. The Sub-G1 peak referred to cells with DNA content less than G1, which were usually regarded as cell death. Results of PI stained implied that cell death rate of A549 cells was $5.32 \pm 0.63 \%$ by GNA, 3.94士 $0.53 \%$ by $5-\mathrm{FU}, 27.00 \pm 1.35 \%$ by the combination of GNA and $5-\mathrm{FU}, 20.41 \pm 1.99 \%$ by z-VAD-fmk and combination, $10.13 \pm$ $1.86 \%$ by Nec-1 and combination for $12 \mathrm{~h}$ incubation (Fig. 2A). It showed that the combination of GNA and 5-FU induced significant higher cell death rate of A549 cells than that of $5-\mathrm{FU}$ or GNA alone. Z-VAD-fmk or Nec-1 blocked the cell death induced by the combination of GNA and 5-FU. Thus, we hypothesized that 5-FU combined with GNA induced cell injury by necroptosis primarily, and apoptosis posteriorly. Compared with control group, apoptotic and necroptotic rates were increased progressively in A549 cells treated with $1 \mu \mathrm{M}$ GNA or $363.3 \mu \mathrm{m} 5$-FU for $24 \mathrm{~h}$, the percentage of the $\mathrm{AV}^{+}$ increased dramatically, and the effect of the combined drugs was stronger than those of GNA or 5-FU alone, while $\mathrm{PI}^{-}$cells were very low (Fig. 2Bi). It also showed that the percentage of the $\mathrm{AV}^{+} / \mathrm{PI}^{-}$increased at $24 \mathrm{~h}$, and it showed that the effects were time-dependent manners in A549 cells treated with the combination of $1 \mu \mathrm{M}$ GNA and $363.3 \mu \mathrm{M} 5-\mathrm{FU}$, respectively for 0, 6, 12 and 24h (Fig. 2Bii).

Mitochondrial Dysfunction by 5-FU, GNA or the Combination of GNA and 5-FU As shown in Fig. 3A, MMP decreased in response to GNA or 5-FU alone or the combination of GNA and 5-FU for $24 \mathrm{~h}$. Cells treated with GNA showed a $13.7 \pm 1.84 \%$ loss in membrane potential compared with control $(p<0.01)$. Cells treated with 5 -FU showed a $22.2 \pm 3.21 \%$ loss in membrane potential compared with control $(p<0.01)$. Cells treated with the combination showed a $53.2 \pm 2.72 \%$ loss in membrane potential compared with control $(p<0.01)$.

As shown in Fig. 3B, JC-1 red fluorescence $\left(\mathrm{FL}-2^{+}\right)$was 

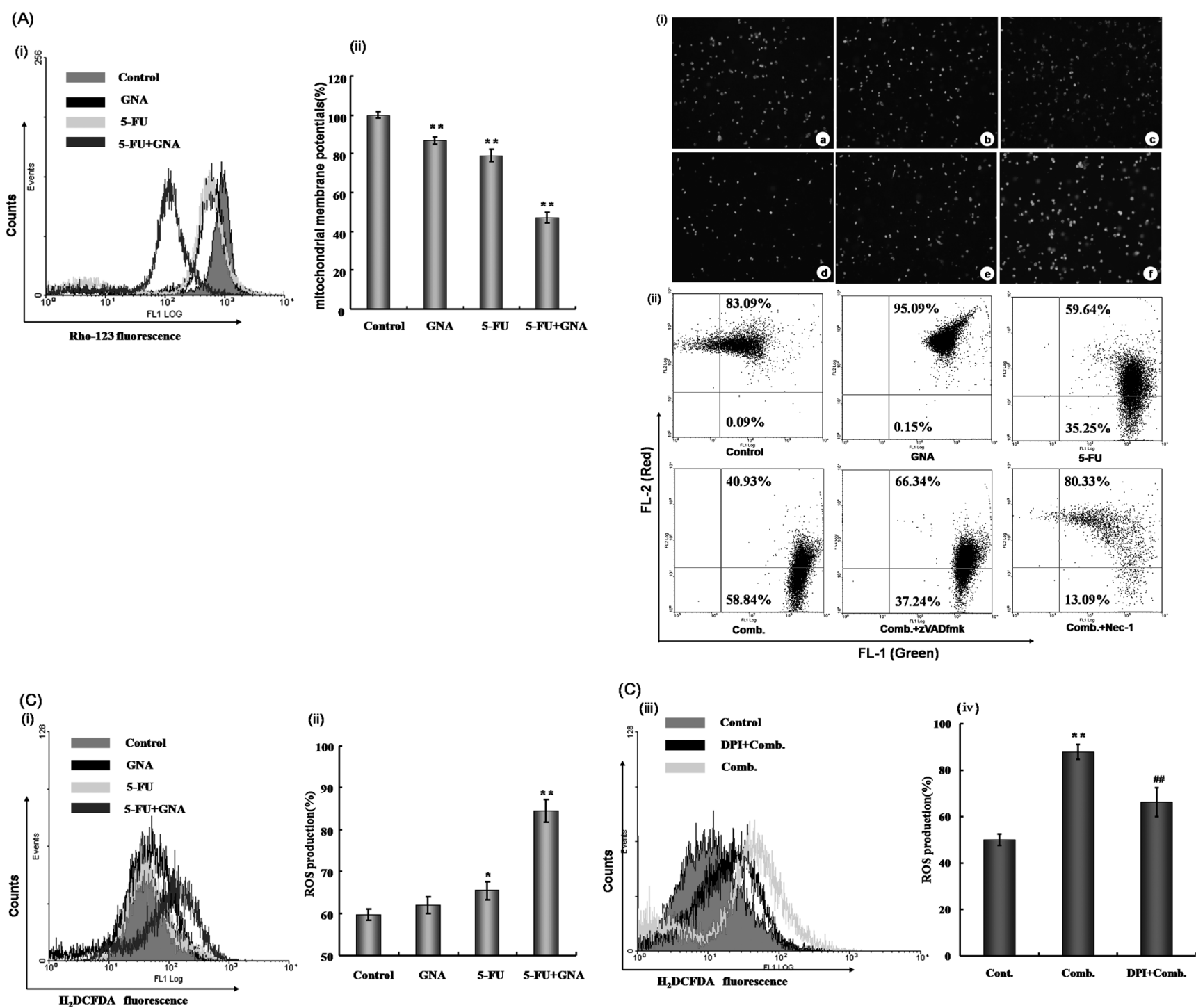

Fig. 3. Effects of GNA or 5-FU or Combination on Cells Showed Cytotoxicity of Mitochondria

Mitochondrial membrane potential is detected using Rho-123 stain (10 mg/mL) (A). Mitochondrial membrane potential as detected by JC-1 fluorescence. A549 cells were stained with $2 \mu \mathrm{g} / \mathrm{mL}$ of JC-1 for $30 \mathrm{~min}$ at $37^{\circ} \mathrm{C}$, then trypsinized to provide a single cell suspension and analyzed for green (FL-1) and red (FL-2) fluorescence by photomicrographs (Leica, Germany) (Bi), under fluorescence microscope, cells displayed orange in control (a), and cells treated with GNA cells were turned green (b), 5-FU (c), 5-FU with GNA (d), z-VAD-fmk with combination (e), Nec-1 with combination (f), photos reveal punctate nonnuclear red-orange staining characteristic of JC-1 accumulation in respiring mitochondria. Different drugs-treatment caused decrease in number and intensity of red-stained mitochondria while slightly increasing the green intensity of cytoplasmic JC-1. Magnification $=\times 200$, flow cytometry (Bii), respectively. Reactive oxygen species levels in mitochondria were detected to use DCFH-DA staining (C). (Color images were converted into gray scale.)

lower in response to GNA or 5-FU alone or the combination of GNA and 5-FU for $24 \mathrm{~h}$. At the same time, z-VAD-fmk or Nec-1 partially offset the effect of combination treatmentinduced the loss of JC-1 red fluorescence. Results implied that JC-1 red fluorescence loss rate of A549 cells was $8.15 \pm 5.01 \%$ by GNA $(p<0.01), 29.4 \pm 5.20 \%$ by 5 -FU $(p<0.05), 52.47 \pm$ $7.12 \%$ by the combination of GNA and 5-FU $(p<0.01), 28.41 \pm$ $5.38 \%$ by $z-V A D-f m k$ and combination $(p<0.01), 18.44 \pm$ $2.77 \%$ by Nec-1 and combination $(p<0.01)$. Meanwhile, JC-1 green fluorescence $\left(\mathrm{FL}-1^{+}\right)$was higher in cells treated with GNA, 5-FU or combination treatment. At the same time, zVAD-fmk or Nec-1 partially offset the effect of combination treatment-induced the enhancement of JC-1 green fluorescence. Results implied that JC-1 green fluorescence enhancement rate of A549 cells was $10.08 \pm 4.84 \%$ by GNA $(p<0.01)$, $14.31 \pm 4.26 \%$ by $5-\mathrm{FU}(p<0.05), 20.90 \pm 6.33 \%$ by the combi- nation of GNA and 5-FU $(p<0.01), 16.02 \pm 6.50 \%$ by z-VADfmk and combination $(p<0.01), 0.99 \pm 4.13 \%$ by Nec-1 and combination $(p<0.01)$.

Intracellular ROS generation was evaluated by using intracellular peroxide-dependent oxidation of DCFH-DA to form fluorescent DCF. DCF fluorescence was detected after the cells treated with GNA or 5-FU alone or with combination for $24 \mathrm{~h}$ (Fig. 3Ci). The production of ROS was significantly increased in the treatment of drug combination compared with control $(p<0.01)$ (Fig. 3Cii). Compared to those results of GNA or 5-FU alone treatment, the combination treatment group was significantly changed. As shown in Figs. 3Ciii, iv, pretreated with DPI, the production of ROS A549 cells was significantly decreased compared with combination treatment for 24h (\#\# $p<0.01)$.

As shown in Fig. 3D, VDAC, cytochrome $c$, cyclophilin D 
(D)

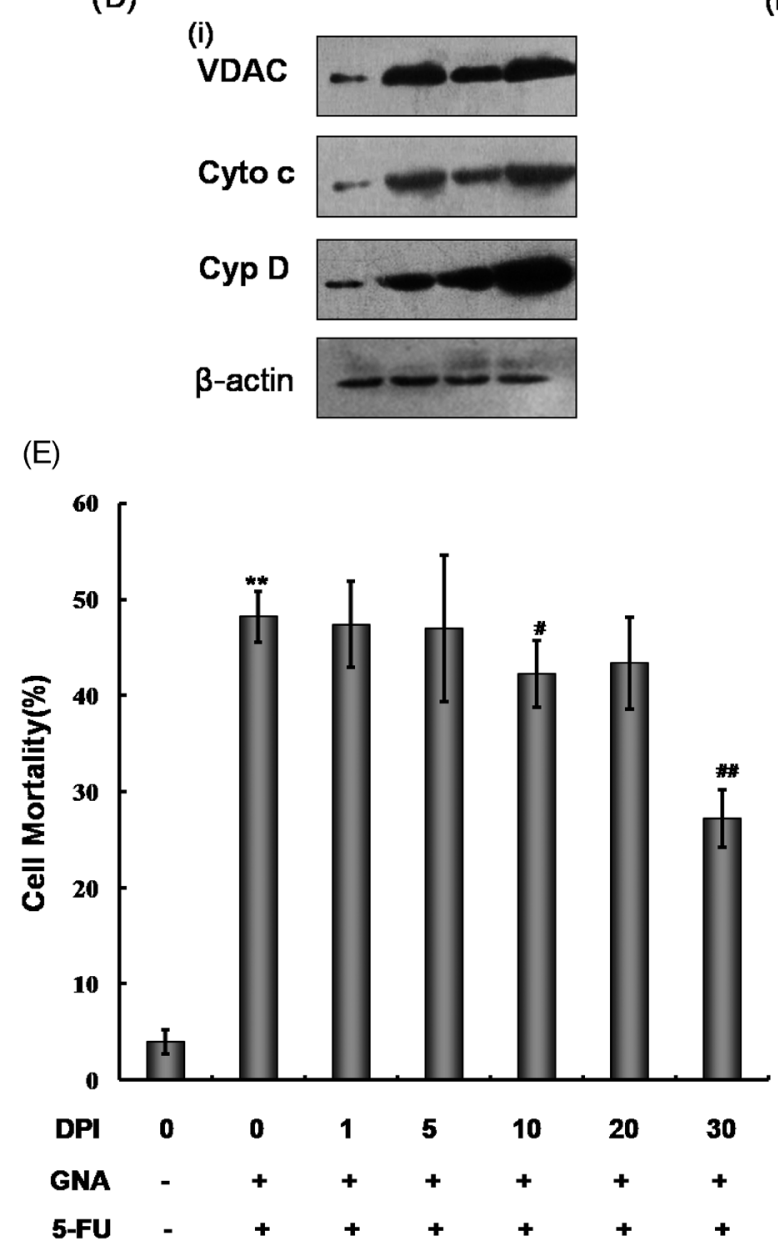

(ii)
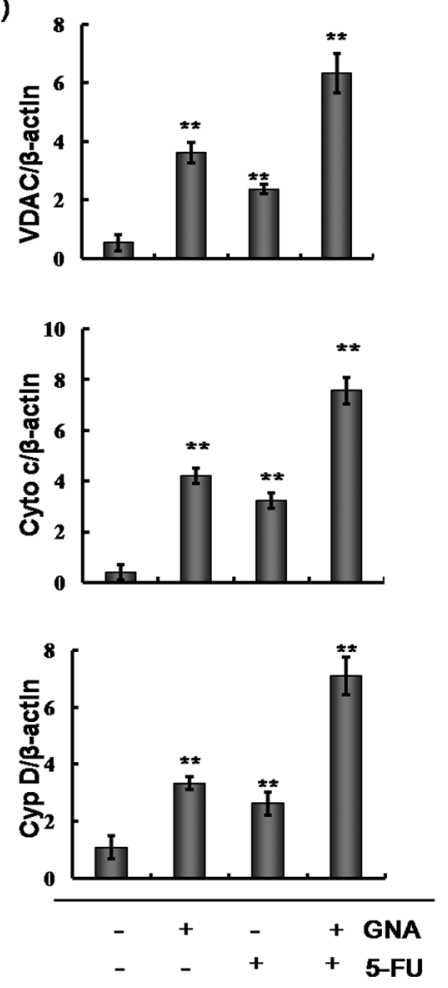

(F)
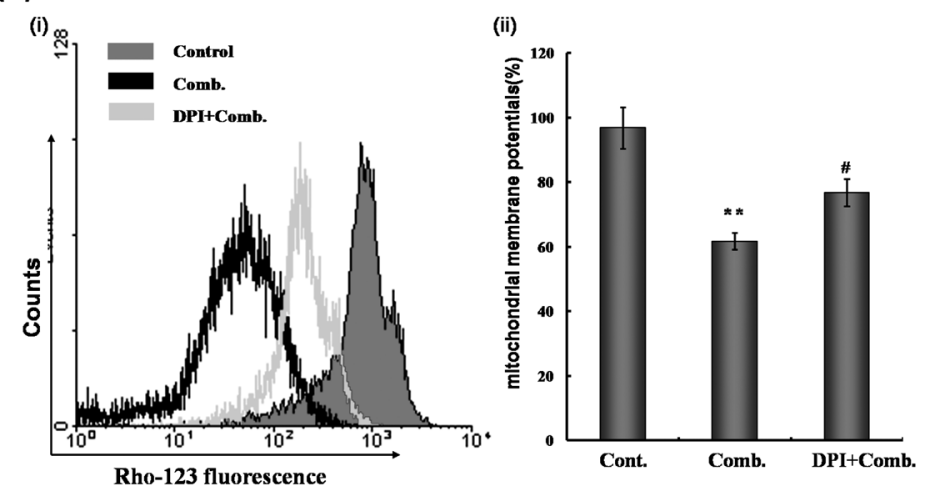

Fig. 3. (Continued.)

ROS inhibitor, DPI with different concentration blocked GNA and 5-FU-induced cell death. Data showed represent means and standard error of mean (S.D.) at least 3 independent experiments, ${ }^{* *} p<0.01$ compared with drug free group, ${ }^{\#} p<0.05,{ }^{\#} p<0.01$ compared with drugs combination treated group (D). Western blot analyzed the protein expression of VDAC, cytochrome $c$, cyclophilin D (Cyp D) (E). Mitochondrial membrane potential of cells treated with DPI and combination or combination, it was detected by Rho-123 stain (F).

were up-regulated in cultures treated with both signle-drug treatment and a combinational treatment compared with control $(p<0.01)$.

Cell Mortality While viability showed the activity of cell mitochondria, the mortality indicated the death of cell. The cell mortality was monitored by Trypan blue exclusion assay, in which the dead cells were stained into blue while the alive ones remained unchanged. Mortality was expressed by the ration of dead cells in all cells. While there was the viability loss induced by drugs, no mortality increase of A549 cells was observed after GNA and 5-FU combination treatment (Fig. 3E), compared to the control group. The mortality of low dose DPI remained around $4.5 \%$ upon the exposure, nearly the same as that of the combination group (47.19\%). Based on the above result, the best concentration of DPI was $30 \mu \mathrm{m}$.

As shown in Fig. 3F, MMP decreased in response to a combination of GNA and 5-FU or combination treatment after $30 \min 30 \mu \mathrm{M}$ DPI pretreatment for $24 \mathrm{~h}$.

These data of the above two parts indicated that 5-FU combined with GNA induced cell injury was primarily necropto- 

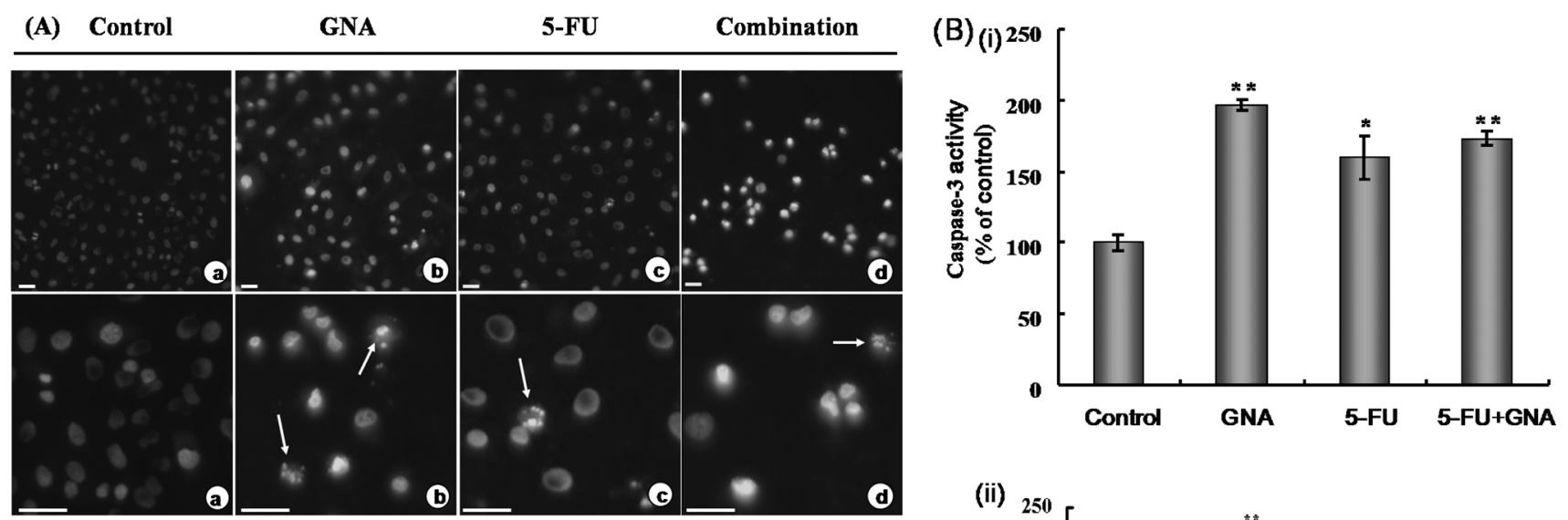

(C)
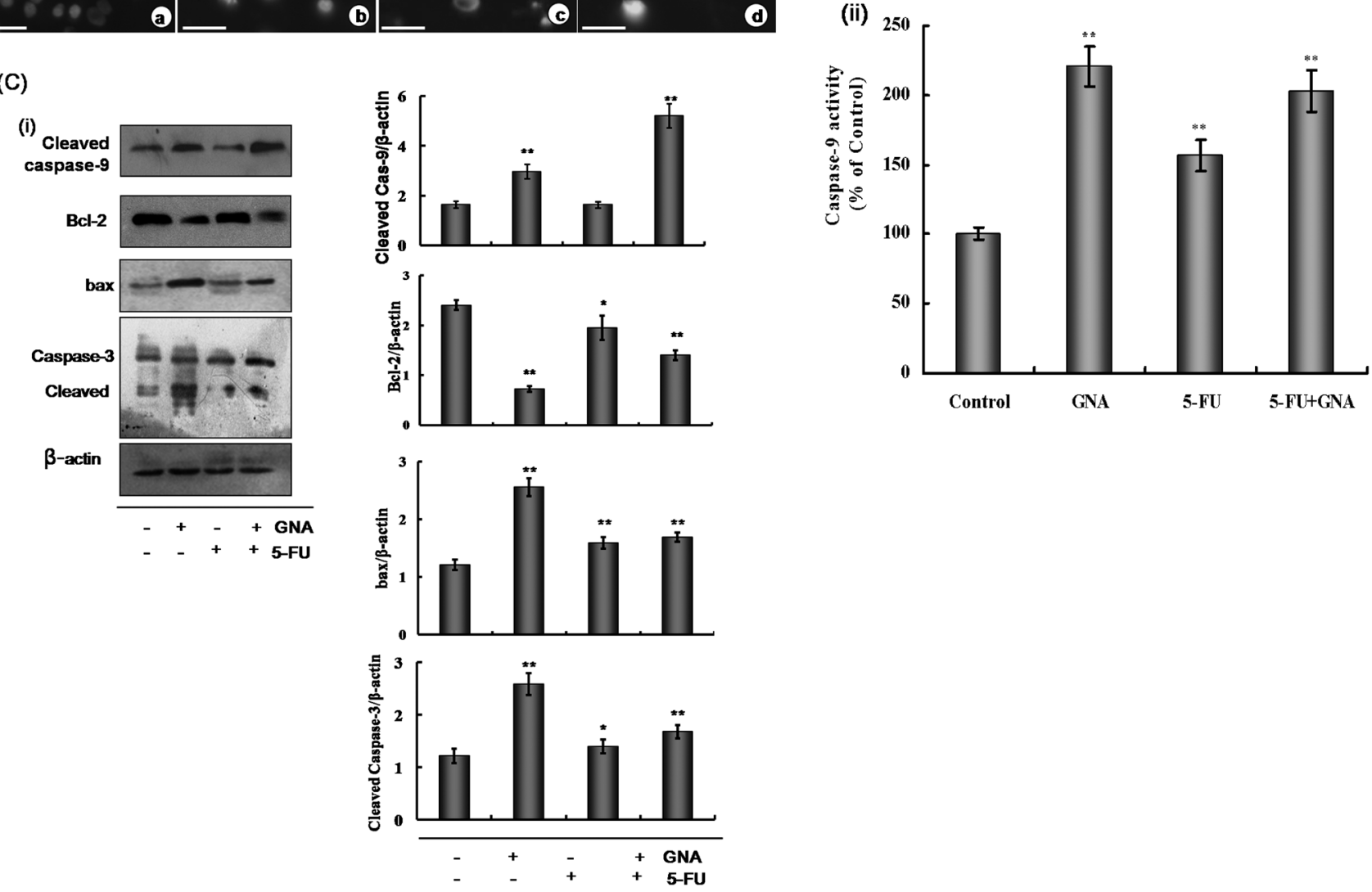

Fig. 4. Hoechst Staining Representative Photomicrographs of A549 Cells Were Harvested and Detected with Hoechst Staining (A)

Under fluorescence microscope, nucleus displayed blue in control (a), and cells treated with GNA appeared apoptotic body (b), 5-FU (c), 5-FU with GNA (d), arrow indicating apoptotic body, bar, $20 \mu \mathrm{m}(\mathrm{a}-\mathrm{d})$. (Color images were converted into gray scale.) GNA or 5-FU or combination triggers apoptosis by activaing caspase-3 in A549 cells. Caspase-3 activation was detected to use DEVD-pNA as substrate (Bi). Caspase-9 activation was detected to use LEHD- $p$ NA as substrate. The concentrations of the fluorescent products released were then measured by MD M2e microplate reader (Bii). Western blot analysed the protein expression of caspase-3, caspase-9, bax, bcl-2(C).

sis, and posteriorly apoptosis. ROS-mitochondrial mechanism contributed to the cell death induced by the combination of drugs.

Apoptosis Induced by Drug Combination of GNA and 5-FU Hoechst 33258 stained assay was used to confirm cell apoptosis in this study. The apoptotic cells characterized by condensed or fragmented nuclei which were observed after treatment of GNA or 5-FU alone, or in combination of GNA and 5 -FU for $24 \mathrm{~h}$ (Fig. 4A).

The activation of caspase-3 was evaluated in cells treated with GNA or 5-FU or the combination for $24 \mathrm{~h}$. As shown in Fig. 4B, activation of caspase-3 was increased in cultures treated both with signle drug treatment and the combinational treatment compared with control $(p<0.01)$ (Fig. 4B). Bcl-2 played a key role in apoptosis, therefore the $\mathrm{Bcl}-2$ associated protein expressions in A549 cells were examined. Caspase-3, caspase-9, bax were up-regulated, however, bcl-2 protein was down-regulated (Fig. 4C). Compared to those results of single drug treatment, the combinational treatment group was not significantly changed. These data indicated that caspase-independent, non-apoptotic mechanisms also contributed to the cell death induced by the combinational treatment.

Necroptosis Expressions Induced by the Combination of GNA and 5-FU Under electron microscope (Fig. 5A), after being cultured with GNA $1 \mu \mathrm{M}$ for $24 \mathrm{~h}$, dotted chromatins were found. Few cells showed condensed chromatin divided into "Apoptosis bodies." Similar to necroptosis, a typical cellular necrotic death was induced by the combination of GNA and 5 -FU for $24 \mathrm{~h}$. The combinational treatment caused a loss of mitochondrial membrane potential if the combinational 

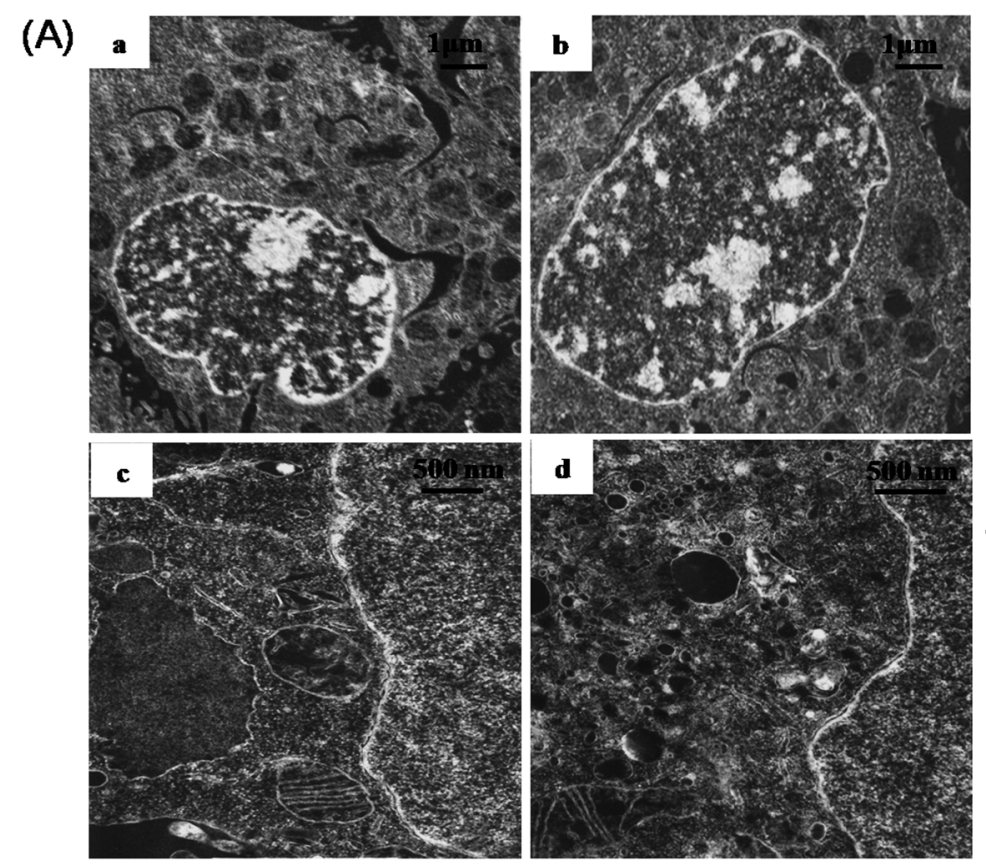

(B)

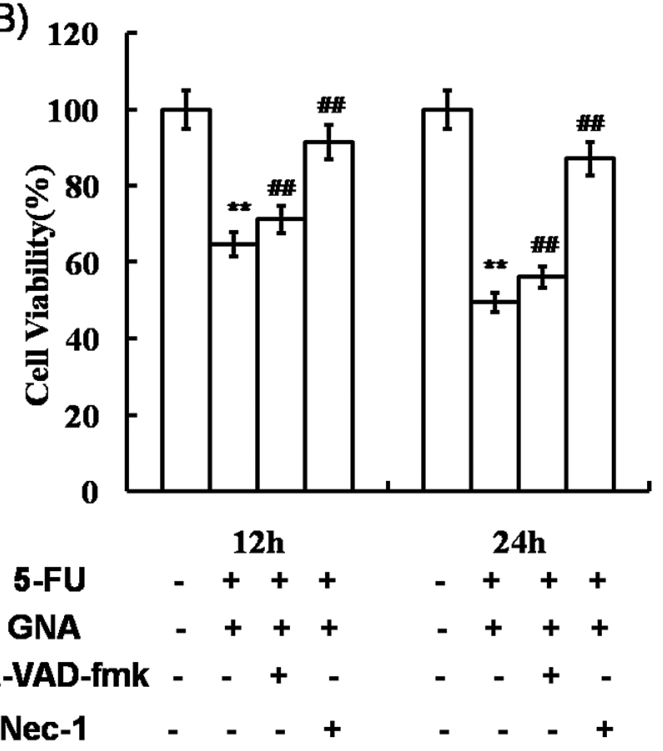

(C)
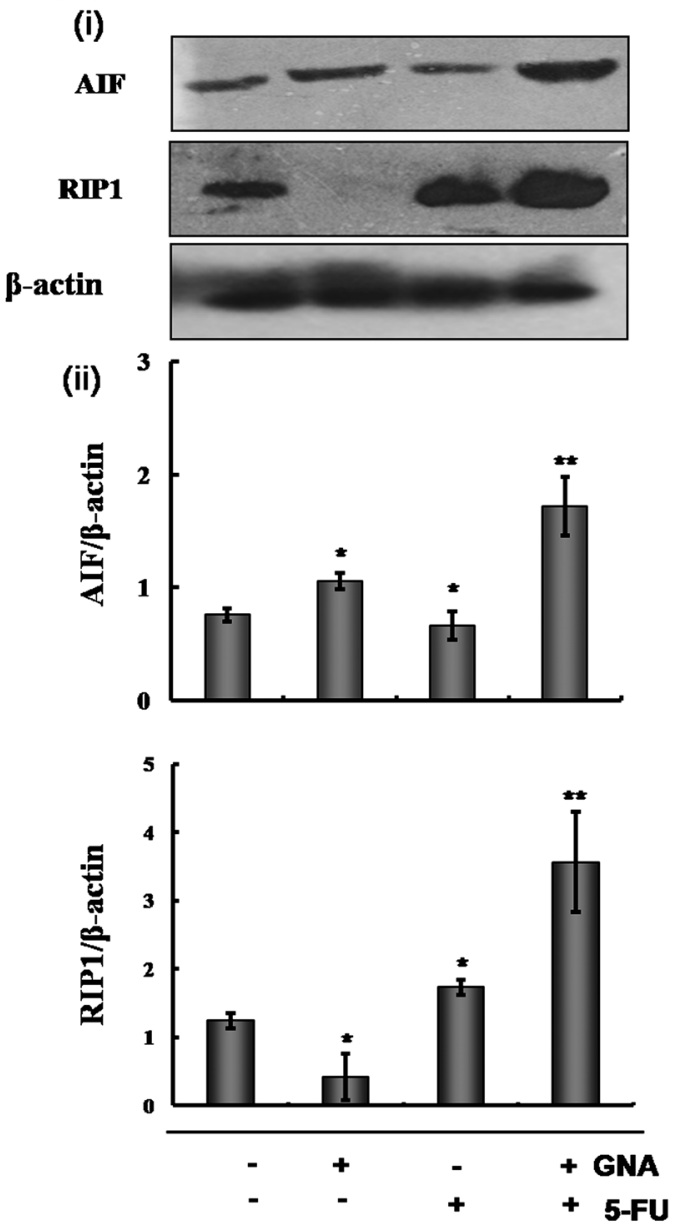

Fig. 5. Transmission Electron Micrograph (A) Showed Nucleus in Control (a), A549 Cells Treated with Combination, Showing Swollen Nucleus (b), Numerous Swollen Mitochondria (c), Severe Damage of Mitochondria with Disrupted Internal Structures (d)

Bar, $1 \mu \mathrm{m}(\mathrm{a}-\mathrm{b})$ and $500 \mathrm{~nm}(\mathrm{c}-\mathrm{d})$. Caspase-3 inhibitor z-VAD-fmk or Rip1 inhibitor Nec-1 blocked GNA and 5-FU-induced cell death. Data has been shown represent means and standard error of mean (S.D.) at least in 3 independent experiments. ${ }^{* *} p<0.01$ compared with drug free group, ${ }^{\#} p<0.01$ compared with drugs combination treated group (B). Western blot analyzed the protein expression of AIF, RIP1 (C).

treatment of GNA and 5-FU activated necroptosis. It was able to protect A549 cells against drug induced cell death combining with z-VAD-fmk and Nec-1 which provided increased protection. Combinational treatment of GNA and 5-FU caused a loss of mitochondrial membrane potential. By measuring cellular viability of A549, treatment of A549 cells with z-VADfmk showed that GNA or 5-FU caused cellular death of A549 cells, treatment of A549 cells with Nec-1 counteracted the effect of the combination of GNA and 5-FU (Fig. 5B). Overexpressed protein of RIP1 was a specific necroptosis target ${ }^{17)}$ as showed in Fig. 5C. These results suggested that the combinational treatment of GNA and 5-FU induced necroptosis which was also known as a non-apoptotic cellular death. And, was primarily necroptosis, posteriorly, was apoptosis.

\section{DISCUSSION}

5-FU is currently considered as a key drug in clinical chemotherapeutic treatment for cancers. ${ }^{6,18)}$ It has been shown that 5 -FU can induce cell-cycle arrest, ${ }^{19)}$ apoptosis ${ }^{20)}$ and necrosis. ${ }^{21)}$ The cytotoxicity mechanism of 5-FU is related to drug concentration, duration of exposure, and biological status of the target cells. In recent years, the interest in exploiting traditional medicines for prevention or treatment of tumors has increased. ${ }^{22-24)}$ Recent studies show that GNA is cytotoxic to various types of tumor cells and contained significant antiproliferative and apoptotic effect for tumor cells.

Therefore, combined treatments by using chemotherapeutic drugs and traditional medicines are often applied not only to 
enhance the treatment effect, but also to reduce the toxicity. ${ }^{25)}$

Although A549 cell line is not sensitive to 5-FU, we have found that 5-FU combined with GNA has a synergistic effect unexpectedly. It also has precedents that 5-FU was used for lung cancer, ${ }^{26,27)}$ although 5 -FU is not the first choice. We try to find the possible mechanism, expand the anti-tumor spectrum of 5-FU, pave the way for broader clinical application. In this study, we investigated the inhibitory effect of 5-FU combined with GNA on A549 cells in vitro. We found that GNA or 5-FU alone inhibited the proliferation of A549 cells in a dose-dependent manner significantly $\left(\mathrm{IC}_{50}\right.$ of GNA was $2.832 \mu \mathrm{M}$; and was $1073 \mu \mathrm{M}$ for $5-\mathrm{FU})$. The combined inhibitory effect of GNA and 5-FU with fixed concentrations on the growth of human lung cells was stronger than that of GNA or 5-FU alone. It showed that synergistic effect occurred at higher concentrations of the combined drugs and the antineoplastic spectrum.

These results obtained from this study were attractive and would encourage the further research for understanding the mechanism of synergistic effect. Flow cytometric results showed that treatment of the combination of GNA and 5-FU induced cell death and mitochondrial damage, which the effect were significantly stronger than that of single treatment by using GNA or 5-FU alone. Observations of fluorescence microscopy showed apoptotic feature, but results of transmission electron microscopy showed a necrosis-like feature which was different from apoptosis. The interesting ambiguity promoted us to make a further investigation.

Apoptosis (or programmed cell death) was recognized as an orderly and genetically controlled cell death which was firstly introduced by Kerr. ${ }^{18)}$ Mitochondrial homeostasis was also shown to play a pivotal role in regulating apoptosis. ${ }^{28)}$ Pro-apoptosis signals triggered the mitochondria to release caspase-activating proteins into cytosol, such as cytochrome $c$, and reduced mitochondrial transmembrane potential which upstreamly regulated release of cytochrome $c$. Cyclophilin D have since been identified in various cell compartments. Its functions are poorly understood but have been linked to apoptosis. $^{29)}$

Necroptosis, a programmed cell death pathway, was recently identified by Degterev et al. ${ }^{30)}$ Necroptosis was triggered by the same stimuli that activated apoptosis normally. However, necroptosis was distinct from apoptosis, for it did not involve in key apoptosis regulators such as Bcl-2 family members that bound to VDAC. VDAC expression located in the outer mitochondrial membrane might be the primary means by which the related metabolites diffused in and out of the mitochondria (Hodge et al. 1997). Homodimerization of VDAC might be a mechanism for changing mitochondrial permeability and supporting release of cytochrome $c$ (Zheng et al. 2004). Furthermore, it is characterized by specific morphological changes of necrotic cell death. The cellular morphology of necroptotic death, including early loss of the integrity of plasma membrane, lack of nuclear fragmentation, mitochondrial dysfunction and oxidative stress, which were very similar to that of necrosis. Notably, cell death with necrotic features is prevalent in an array of acute human pathologies including myocardial infarction, cerebral ischemia and acute organ failure. However, inhibition of necrosis currently has not been perceived as a viable therapeutic strategy because necrosis is believed to be an unregulated process caused by overwhelm- ing external stress. Apoptotic and programmed necrosis, were well validated in many instances of pathologic injury. ${ }^{31)}$ The discovery of necroptosis offered the possibility that a subset of pathologic necrotic cell death was regulated by a distinct cellular mechanism, and therefore was amenable to therapeutic intervention. Geldanamycin, a specific ATP-competitive inhibitor of Hsp90, had been reported that can inhibit RIP1 kinase-dependent necroptosis while RIP1 is a client protein of Hsp90. ${ }^{17)}$ Necroptosis had been shown to link to rapid mitochondrial dysfunction that led to the excessive production of reactive oxygen species. Thus, it remained formally possible that a sudden breakdown of mitochondrial function caused a drop of intracellular ATP concentration might account for the bioenergetic crisis and constitute the final step of programmed necrosis. ${ }^{22}$ Apoptosis-inducing factor (AIF) was a phylogenetically ancient mitochondrial intermembrane flavoprotein that was endowed with the unique capacity to induce caspaseindependent death. ${ }^{32)}$ In this study, we examined the apoptosis and necroptosis induced by GNA or 5-FU through Western blotting analysis, and investigated the pharmacogenetic variability of apoptosis-related proteins, such as caspase-3, caspase-9, bax, bcl-2, and necroptotis-related protein such as RIP1. These results showed activation of caspase, bax especially RIP1 and AIF protein and inactivation of bcl-2 protein by the treatments.

It had been proved that activation of apoptosis and necroptosis occurred at the same time sequence in cancer cells. ${ }^{21,33,34)}$ In this study, we showed that at least two programmed cell death mechanisms (apoptosis and necroptosis) were both activated in these treatments.

Increased oxidative stress mediated by ROS had implicated in a variety of kidney diseases, which caused cell damage by lipid peroxidation, DNA breakdown, and protein damage. ROS-induced mitochondrial dysfunction, caspase family activation, which contributed to both necrotic and apoptotic forms of cell death. ${ }^{22)}$ Both apoptosis and necroptosis were linked to mitochondrial dysfunction that led to the excessive production of reactive oxygen species.

In conclusion, results from this study showed that gambogenic acid combined with 5-FU inhibited cell proliferation through increasing the mitochondrial oxidative stress in A549 cells. These results also suggested that a molecular mechanism that 5-FU combined with GNA induced cell injury was primarily necroptosis, posteriorly apoptosis. And necroptosis and apoptosis might take place through the mitochondrial oxidative stress. Although mitochondrial pathway might take place through different ways by GNA or 5-FU activation, the most likely synergistic effect of GNA and 5-FU on A549 cells is significant, and the path might go through both caspasedependent apoptotic and caspase-independent necroptotic pathways. And, subsequent research is ongoing

Acknowledgments The research was supported by Natural Science Foundation of China (81173600), Natural Science Foundation of Anhui Province (11040606M190), Natural Science Foundation of Anhui University of Traditional Chinese Medicine (2012zr017) and Natural Science Foundation of Anhui University of Traditional Chinese Medicine (No. 2010zr015B). It was also supported by Asia University, Taiwan (Asia U-98-NSC-07 and Asia U-100-A-05). 


\section{REFERENCES}

1) Fitzgerald JB, Schoeberl B, Nielsen UB, Sorger PK. Systems biology and combination therapy in the quest for clinical efficacy. Nat. Chem. Biol., 2, 458-466 (2006).

2) Okon T, Schwartzberg L. Are we winning the war on cancer? $J$. Oncol. Pract., 7 (Suppl.), 62s-64s (2011).

3) Adjei AA, Budihardjo II, Rowinsky EK, Kottke TJ, Svingen PA, Buckwalter CA, Grochow LB, Donehower RC, Kaufmann SH. Cytotoxic synergy between pyrazoloacridine (NSC 366140) and cisplatin in vitro: Inhibition of platinum-DNA adduct removal. Clin. Cancer Res., 3, 761-770 (1997).

4) Wang W, Yang SM, Su Y, Xiao ZY, Wang CY, Li XF, Lin L, Fenton BM, Paoni SF, Ding I, Keng P, Okunieff P, Zhang L. Enhanced antitumor effect of combined triptolide and ionizing radiation. Clin. Cancer Res., 13, 4891-4899 (2007).

5) Murata S, Adachi M, Kioi M, Torigoe S, Ijichi K, Hasegawa Y, Ogawa T, Bhayani MK, Lai SY, Mitsudo K, Tohnai I. Etodolac improves 5-FU sensitivity of head and neck cancer cells through inhibition of thymidylate synthase. Anticancer Res., 31, 2893-2898 (2011).

6) Ueda M, Kumagai K, Ueki K, Inoki C, Orino I, Ueki M. Growth inhibition and apoptotic cell death in uterine cervical carcinoma cells induced by 5-fluorouracil. Int. J. Cancer, 71, 668-674 (1997).

7) Tsai CM, Hsiao SH, Frey CM, Chang KT, Perng RP, Gazdar AF, Kramer BS. Combination cytotoxic effects of cisdiamminedichloroplatinum(II) and 5-fluorouracil with and without leucovorin against human non-small-cell lung-cancer cell-lines. Cancer Res., 53, 1079-1084 (1993).

8) Lei QM, Liu JM. Retrospect and prospect of anti-cancer efficacy of gamboge. China J. Cancer Prev. Treat., 10, 216-219 (2003).

9) Chen HB, Zhou LZ, Mei L, Shi XJ, Wang XS, Li QL, Huang LQ. Gambogenic acid-induced time- and dose-dependent growth inhibition and apoptosis involving Akt pathway inactivation in U251 glioblastoma cells. J. Nat. Med., 66, 62-69 (2012).

10) Cheng H, Su JJ, Peng JY, Wang M, Wang XC, Yan FG, Wang XS, Li QL. Gambogenic acid inhibits proliferation of A549 cells through apoptosis inducing through up-regulation of the p38 MAPK cascade. J. Asian Nat. Prod. Res., 13, 993-1002 (2011).

11) Li Q, Cheng H, Zhu G, Yang L, Zhou A, Wang X, Fang N, Xia L, Su J, Wang M, Peng D, Xu Q. Gambogenic acid inhibits proliferation of A549 cells through apoptosis-inducing and cell cycle arresting. Biol. Pharm. Bull., 33, 415-420 (2010).

12) Yan F, Wang M, Chen H, Su J, Wang X, Wang F, Xia L, Li Q. Gambogenic acid mediated apoptosis through the mitochondrial oxidative stress and inactivation of Akt signaling pathway in human nasopharyngeal carcinoma CNE-1 cells. Eur. J. Pharmacol., 652, 23-32 (2011).

13) Yan F, Wang M, Li J, Cheng H, Su J, Wang X, Wu H, Xia L, Li X, Chang HC, Li Q. Gambogenic acid induced mitochondrial-dependent apoptosis and referred to Phospho-Erk1/2 and Phospho-p38 MAPK in human hepatoma HepG2 cells. Environ. Toxicol. Pharmacol., 33, 181-190 (2012).

14) Chou T-C. Drug combination studies and their synergy quantification using the Chou-Talalay method. Cancer Res., 70, 440-446 (2010).

15) Saito M, Kobayashi M, Iwabuchi SI, Morita Y, Takamura Y, Tamiya E. DNA condensation monitoring after interaction with Hoechst 33258 by atomic force microscopy and fluorescence spectroscopy. $J$. Biochem., 136, 813-823 (2004).

16) Liu Y, Zhang SP, Cai YQ. Cytoprotective effects of selenium on cadmium-induced LLC-PK, cells apoptosis by activating JNK pathway. Toxicol. In Vitro, 21, 677-684 (2007).

17) Degterev A, Hitomi J, Germscheid M, Ch'en IL, Korkina O, Teng X, Abbott D, Cuny GD, Yuan CY, Wagner G, Hedrick SM, Ger- ber SA, Lugovskoy A, Yuan JY. Identification of RIP1 kinase as a specific cellular target of necrostatins. Nat. Chem. Biol., 4, 313-321 (2008).

18) Kerr JFR. Definition of apoptosis and overview of its incidence. Programmed cell death: the cellular and molecular biology of apoptosis. Harwood Academic Publishers, Amsterdam, the Netherlands, pp. 1-18 (1993).

19) Huang CJ, Yang SH, Huang SM, Lin CM, Chien CC, Chen YC, Lee $\mathrm{CL}, \mathrm{Wu} \mathrm{HH}$, Chang CC. A predicted protein, KIAA0247, is a cell cycle modulator in colorectal cancer cells under 5-FU treatment. $J$. Transl. Med., 9, 82-89 (2011).

20) Tseng YS, Tzeng CC, Chiu AWH, Lin CH, Won SJ, Wu IC, Liu HS. Ha-ras overexpression mediated cell apoptosis in the presense of 5-fluorouracil. Exp. Cell Res., 288, 403-414 (2003).

21) Guchelaar HJ, Vermes I, Koopmans RP, Reutelingsperger CPM, Haanen C. Apoptosis- and necrosis-inducing potential of cladribine, cytarabine, cisplatin, and 5-fluorouracil in vitro: a quantitative pharmacodynamic model. Cancer Chemother. Pharmacol., 42, 77-83 (1998)

22) Fiers W, Beyaert R, Declercq W, Vandenabeele P. More than one way to die: apoptosis, necrosis and reactive oxygen damage. Oncogene, 18, 7719-7730 (1999).

23) Jin S, Zhang QY, Kang XM, Wang JX, Zhao WH. Daidzein induces MCF-7 breast cancer cell apoptosis via the mitochondrial pathway. Ann. Oncol., 21, 263-268 (2010).

24) Tan W, Lu JJ, Huang MQ, Li YB, Chen MW, Wu GS, Gong J, Zhong ZF, Xu ZT, Dang YY, Guo JJ, Chen XP, Wang YT. Anticancer natural products isolated from Chinese medicinal herbs. Chin. Med., 6, 27 (2011).

25) Yang L, Wu DF, Luo KW, Wu SH, Wu P. Andrographolide enhances 5-fluorouracil-induced apoptosis via caspase-8-dependent mitochondrial pathway involving p53 participation in hepatocellular carcinoma (SMMC-7721) cells. Cancer Lett., 276, 180-188 (2009).

26) Lynch TJ, Kass F, Elias AD, Skarin A, Iii EF, Kalish LA, Strauss G, Shulman LN, Sugarbaker DJ. Cisplatin, 5-fluorouracil, and etoposide for advanced non-small cell lung cancer. Cancer, 71, 2953-2957 (1993).

27) Tanaka F, Wada H, Fukushima M. UFT and S-1 for treatment of primary lung cancer. Gen. Thorac. Cardiovasc. Surg., 58, 3-13 (2010)

28) Valmas N, Zuryn S, Ebert PR. Mitochondrial uncouplers act synergistically with the fumigant phosphine to disrupt mitochondrial membrane potential and cause cell death. Toxicology, 252, 33-39 (2008).

29) Parrish JZ, Xue D. Functional genomic analysis of apoptotic DNA degradation in C. elegans. Mol. Cell, 11, 987-996 (2003).

30) Degterev A, Huang ZH, Boyce M, Li YQ, Jagtap P, Mizushima N, Cuny GD, Mitchison TJ, Moskowitz MA, Yuan JY. Chemical inhibitor of nonapoptotic cell death with therapeutic potential for ischemic brain injury. Nat. Chem. Biol., 1, 112-119 (2005).

31) Holler N, Zaru R, Micheau O, Thome M, Attinger A, Valitutti S, Bodmer JL, Schneider P, Seed B, Tschopp J. Fas triggers an alternative, caspase-8-independent cell death pathway using the kinase RIP as effector molecule. Nat. Immunol., 1, 489-495 (2000).

32) Candé C, Cohen I, Daugas E, Ravagnan L, Larochette N, Zamzami N, Kroemer G. Apoptosis-inducing factor (AIF): a novel caspaseindependent death effector released from mitochondria. Biochimie, 84, 215-222 (2002).

33) Horita H, Frankel AE, Thorburn A. Acute myeloid leukemia-targeted toxin activates both apoptotic and necroptotic death mechanisms. PLoS ONE, 3, e3909 (2008).

34) Lock EA, Reed CJ, Kinsey GR, Schnellmann RG. Caspase-dependent and -independent induction of phosphatidylserine externalization during apoptosis in human renal carcinoma Cak(1)-1 and A-498 cells. Toxicology, 229, 79-90 (2007). 